\title{
KALIMAT TANYA DALAM BAHASA MANDAILING: TEORI X-BAR
}

\author{
Soraya Tsamara Zahra dan Mulyadi \\ Fakultas Ilmu Budaya Universitas Sumatera Utara \\ Jalan Universitas No. 19 Kota Medan \\ Surel: soraya.tsamara@gmail.com
}

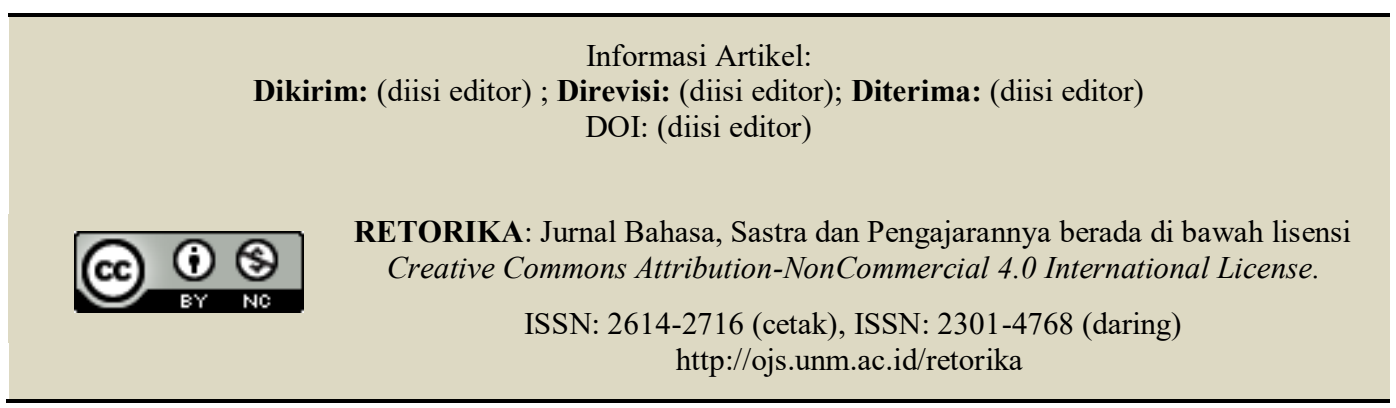

\begin{abstract}
Interrogative Sentence in Mandailing Language: X-bar Theory. This study aims to analyze grammatical and lexical structure in interrogative sentence in Mandailing language. The study of this interrogative sentence structure applies X-bar theory as one of the generative syntax subtheories. This type of research includes qualitative research using distributional method. The data were collected through interview and observation. The result of the study showed that the whquestion in Mandailing language had grammatical function as spesifier and komplement, while the total question sentence had a function as a komplement. Interrogative sentence in Mandailing language formed by spesifiers, komplements, and adverb.
\end{abstract}

Keywords: sintax, interogative sentencem X-bar theory, Mandailing Language

\begin{abstract}
Abstrak: Kalimat Tanya dalam Bahasa Mandailing: Teori X-bar. Artikel ini bertujuan untuk menganalisis struktur kalimat tanya sesuai dengan fungsi gramatikal dan leksikalnya. Penelitian ini menggunakan teori X-bar sebagai kajian sintaksis generatif. Jenis penelitian ini adalah kualitatif dengan metode agih. Dalam pengumpulan data digunakan wawancara dan observasi. Hasil penelitian menunjukkan bahwa kalimat tanya parsial bahasa Mandailing memiliki fungsi gramatikal spesifier dan komplemen, sedangkan kalimat tanya total memiliki fungsi sebagai komplemen. Kalimat tanya bahasa Mandailing dapat dibangun oleh spesifier, komplemen, dan adverbial.
\end{abstract}

Kata kunci: sintaksis, kalimat tanya, teori X-bar, bahasa Mandailing 
Kalimat tanya adalah salah satu bagian dari bentuk komunikasi yang memiliki fungsi penting dalam suatu dialog. Sebagian besar dari komunikasi tesebut adalah bertanya dan menjawab pertanyaan. Kalimat tanya dipergunakan dengan tujuan memperoleh reaksi berupa jawaban dari yang ditanya atau penguatan sesuatu yang telah diketahui oleh penanya. Apa yang disebut dengan kalimat tanya adalah kalimat yang berfungsi untuk menanyakan sesuatu (Alwi, 2003:358; Ramlan, 2005:28). Ketika seseorang baru bertemu dengan orang lain juga menggunakan kalimat tanya untuk menanyakan identitasnya. Dengan demikian, kita selalu menggunakan kalimat tanya setiap harinya dalam suatu percakapan.

Selain untuk mendapatkan informasi, kalimat tanya juga berfungsi untuk menegaskan, mengejek, menyusuh atau memerintah secara halus (Chaer, 2015). Jenis kalimat tanya yang sering digunakan adalah wh-question dan yes/no question. Wh-questions, yaitu siapa, dimana, kapan, mengapa, kemana, bagaimana, sedangkan yes/no question, yaitu benarkah, akankah, maukah, dan sebagainya.

Indonesia memiliki banyak ragam bahasa. Adanya ragam bahasa memungkinkan struktur kalimat yang berbeda-beda dan memiliki cara dalam membentuk kalimat tanya, termasuk dalam bahasa Mandailing. Bahasa Mandailing merupakan bahasa dari Provinsi Sumatera Utara yang hingga saat ini masih banyak digunakan oleh masyarakatnya. Kozok (2009:37) mengatakan bahasa Angkola dan Mandailing adalah dua bahasa yang mempunyai sedemikian banyak persamaan sehingga pada umumnya disebut bahasa Angkola-Mandailing. Penulis memilih bahasa Mandailing untuk dianalisis karena bahasa tersebut masih sering didengar serta menguji apakah kalimat tanya dalam bahasa Mandailing memiliki struktur yang sama dengan bahasa Indonesia atau tidak.

Penelitian struktur kalimat tanya pernah dilakukan sejumlah ahli. Penelitian pertama dilakukan oleh Fitriyani (2018) menjelaskan bahwa bahasa Minangkabau kalimat tanya parsial memiliki dua fungsi gramatikal yaitu spesifier dan komplemen. Kata tanya 'iyonyo' pada kalimat tanya total berfungsi sebagai komplemen. Dalam bahasa Mandailing, Harahap (2018) menganalisis kata tanya dari setiap tipe introgatif. Hasil penelitiannya menunjukkan kata tanya sebagai alat pembentuk kalimat interogatif dapat menandai perbedaan tipe konstruksi interogatif.

Selanjutnya, Hafrianto (2018) membahas struktur kalimat tanya dalam bahasa Melayu dialek Tamiang menggunakan Teori X-bar. Hasil penelitian ini menjelaskan bahwa jenis kalimat tanya total dalam bahasa Melayu dialek Tamiang menggunakan jawaban "ya" atau "tidak", sedangkan jenis kalimat parsial memerlukan jawaban penjelasan atau keterangan.

Penelitian lain tentang teori X-bar dilakukan oleh Mulyadi (2010) tentang frase preposisi bahasa Indonesia. Penelitian ini memberikan stuktur internal dari frase preposisi dalam bahasa Indonesia yang dibentuk oleh komplemen, keterangan, dan spesifier. Penelitian ini menghasilkan kaidah yang dapat dirumuskan (1) $\mathrm{FP}=\mathrm{P}^{\prime}$, Spes; $\mathrm{P}^{\prime}=\mathrm{P}^{\prime}$, Komp, (2) $\mathrm{Fp}=\mathrm{p}^{\prime}$, Spes; $\mathrm{p}^{\prime}=\mathrm{p}^{\prime}$, Ket; $\mathrm{p}^{\prime}=\mathrm{P}$, Komp, (3) FP = P', Spes; FP = $\mathrm{P}^{\prime}$, Spes; $\mathrm{P}^{\prime}=\mathrm{P}$, Ket; $\mathrm{Y}=\mathrm{P}$, Komp.

Penelitian struktur kalimat tanya dengan menggunakan teori X-bar dalam bahasa Mandailing jarang atau belum ditemukan. Pada bahasa lain, penelitian sudah dilakukan dengan menggunakan teori yang mutahir yaitu, teori Xbar.

Bahasa Mandailing memiliki kata tanya yang membentuk kalimat Tanya, seperti bahasa Indonesia. Penulis akan mengulas lebih dalam menggunkan teori X-bar. Dalam penelitian ini, penulis menggunakan teori tersebut untuk menganalisis atau menguji struktur kalimat tanya dalam bahasa Mandailing. Teori X-bar adalah teori lanjutan dari Transformasi Gramatika Generatif yang bertujuan untuk membagi unsur gramatikan secara sistematik dalam satu kalimat yang lengkap.

Bahasa Mandailing memiliki struktur kalimat deklaratif yang sama dengan bahasa Indonesia. Dapat dilihat pada contoh (1) dan (2):

1. Ayah akan pulang ke Medan besok. (Indonesia)

2. Ayah giot mulak tu medan ancogot. (Bahasa Mandailing)

Dapat dilihat persamaan struktur kalimatnya dengan menggunakan teori X-bar pada gambar (1) dan (2).

Selain kalimat deklaratif, kalimat tanya dalam bahasa Mandailing juga memiliki stuktur yang sama 
dengan bahasa Indonesia. Hal ini dapat dilihat pada kalimat (3) dan (4).

3. Kapan kita akan berjumpa?

(Bahasa Indonesia)

4. Andigan doma hita pasuo?

( Bahasa Mandailing )

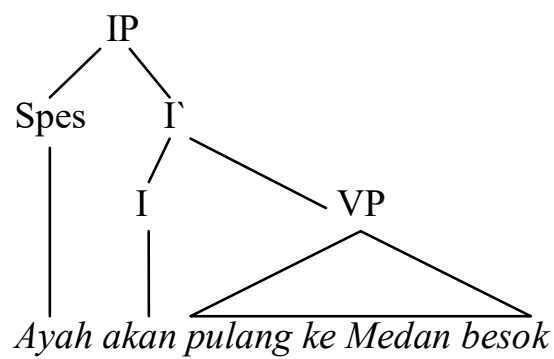

Gambar 1. Struktur Kalimat Deklaratif Bahasa Indonesia

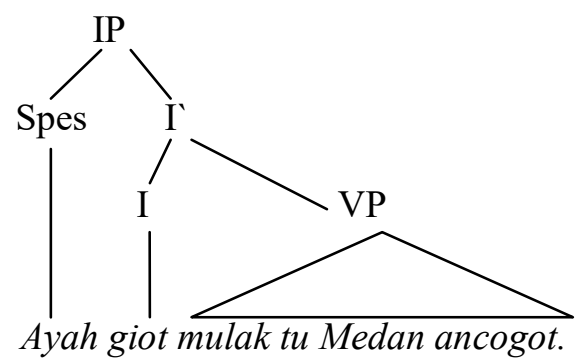

\section{Gambar 2. Struktur Kalimat Deklartif Bahasa Mandailing}

Penelitian ini bertujuan untuk menganalisis struktur kalimat tanya dalam bahasa Mandailing menggunakan teori X-bar dan melihat fungsi gramatikal yang terdapat pada jenis-jenis kalimat Tanya serta kategori leksikal, meliputi komplemen, adverbia, dan spesifier.

\section{METODE}

Kajian ini merupakan penelitian kualitatif. Menurut Sugiyono (2013) penelitian kualitatif adalah penelitian yang lebih menekankan pada informasi dan data yang terkumpul berbentuk dalam kata-kata atau gambar sehingga tidak menekankan pada angka. Hal ini senada dengan pendapat Sutopo (2002: 111) yang menyatakan bahwa penelitian deskriptif kualitatif mengarah pada pendeskripsian secara rinci dan mendalam mengenai potret kondisi tentang apa yang sebenarnya terjadi menurut apa adanya di lapangan studinya.
Data dan sumber data dalam penelitian ini adalah kalimat tanya dalam bahasa Mandailing yang diperoleh dari sumber data, yaitu penduduk dan penutur asli bahasa Mandailing yang berada di kota Gunung Tua, Kabupaten Padang Lawas, Sumatera Utara. Dalam hal ini, penulis memilih informan yang memiliki pengetahuan dan menguasai bahasa Mandailing dengan baik dan benar. Informan berjumlah 2 orang laki-laki yang berkisar umur 35-40 tahun dan 1 orang perempuan berumur 45 tahun.

Penelitian dilakukan dengan mengumpulkan data verbal. Data yang dikumpulkan melalui metode wawancara dan observasi. Dalam metode wawancara, subjek ditanya cara menanyakan sesuatu atau cara bertanya secara interogatif dalam bahasa Mandailing. Dalam metode observasi, jawaban dari informan direkam dan dicatat. Teknik analisis data yang digunakan dalam penelitian ini adalah teknik agih. Metode agih menggunakan alat penentu unsur bahasa itu sendiri (Sudaryanto 2015:15), seperti kata (preposisi, kata ingkar, adverbial), fungsi sintaksis (subjek, objek, predikat), klausa, silabel kata, dan sebagainya.

Terdapat dua jenis kalimat tanya dalam bahasa Mandailing yaitu kalimat tanya total dan kalimat tanya parsial. Data kalimat tanya telah dikumpulkan pada Tabel 2.

Tabel 2. Kalimat Tanya pada Bahasa Mandailing

\begin{tabular}{|c|c|}
\hline Kalimat tanya total & Kalimat tanya parsial \\
\hline Aha do na dibuat mi? & $\begin{array}{c}\text { Botul do ho kehe tu Jakarta } \\
\text { atcogot? }\end{array}$ \\
\hline $\begin{array}{l}\text { Ise do nadi pio ni umak } \\
\text { di poken? }\end{array}$ & Ra doho jadi adaborukku? \\
\hline $\begin{array}{l}\text { Andigan doma hita } \\
\text { pasuo? }\end{array}$ & Adong do huting $i$ di kandang? \\
\hline $\begin{array}{l}\text { Aso inda roho tu } \\
\text { sikolah? }\end{array}$ & $\begin{array}{c}\text { Madung mamaso pinggan do } \\
\text { ho? }\end{array}$ \\
\hline $\begin{array}{l}\text { Aso inda roho tu } \\
\text { sikolah? }\end{array}$ & Tabo do panganon i? \\
\hline $\begin{array}{l}\text { Idia doho malanjutkan } \\
\text { sikolah? }\end{array}$ & Giot do mangan sayur? \\
\hline Sian dia do ia ro? & $\begin{array}{l}\text { Angkon ro do au tu acara } i \\
\text { atcogot? }\end{array}$ \\
\hline $\begin{array}{l}\text { Songan dia do } \\
\text { mambaen kue } i ?\end{array}$ & $\begin{array}{l}\text { Malo ho do mangkarejoon soal } \\
\text { on? }\end{array}$ \\
\hline
\end{tabular}


Berdasakan Tabel 2, data dianalisis dengan metode distribusional dan teknik substitusional yang digunakan untuk mengidentifikasi fungsi leksikal dan gramatikal dari kata tanya tersebut.

\section{Umak mamio donganna di poken.}

$\underline{\text { Ibu memanggil temannya di pasar. }}$

$\begin{array}{llll}\text { NP } & \mathrm{V} & \mathrm{NP} & \mathrm{PP}\end{array}$

6. $\frac{\text { Umak }}{\mathrm{NP}} \frac{\text { mamio }}{\mathrm{V}} \frac{\text { ise }}{\mathrm{NP} \text { PP }}$ di poken.

NP "ibu" diubah menjadi "ise" yang artinya "siapa". Pada tahap ini dapat dilihat bahwa kata tanya "ise" memiliki fungsi leksikal sebagai kata benda sehingga kata tanya "ise" memiliki posisi yang didominasi oleh spesifier.

Untuk menganalisis dan mengidentifikasi data digunakan teori X-bar. Teori X-bar dapat menjelaskan apakah dalam frasa atau klausa dapat memberikan fungsi dari setiap kategori kata. Teori X-bar menggunakan diagram pohon yang dapat melihat struktur dalam kalimat tanya dalam bahasa Mandailing.

\section{HASIL DAN PEMBAHASAN}

\section{Hasil}

Kalimat tanya bahasa Mandailing dapat dibentuk oleh spicifier sebagai struktur internal yang ditempati oleh NP dan bergabung dengan I' membentuk IP. Selanjutnya, kata tanya dalam bahasa Mandailing dapat dibentuk oleh ko-plemen sebagai struktur internal yang ditempati oleh PP atau NP dan bergabung dengan V membentuk V' pertama. Selanjutnya, dapat dibentuk oleh adverbial sebagai struktur internal yang dapat ditempati oleh PP atau NP bergabung ke V' pertama lalu membentuk V' kedua.

Kalimat (7) adalah contoh data yang dikumpulkan berdasarkan jenis penggunaannya.

7. Aso inda roho tu sikolah?

8. Sian dia do ia ro?

9. Giot do mangan sayur?

10. Adong do huting i di kandang?

Kalimat tanya bahasa Mandailing terdiri atas kalimat tanya total dan kalimat tanya parsial. Struktur kalimat parsial yang diawali dengan kalimat tanya parsial akan berubah dari kalimat deklaratif menjadi kalimat tanya seperti contoh analisis berikut ini.

11. a. Uma mamio donganna di poken.

b. Umak mamio ise di poken.

c. Ise na dipio umak di poken?

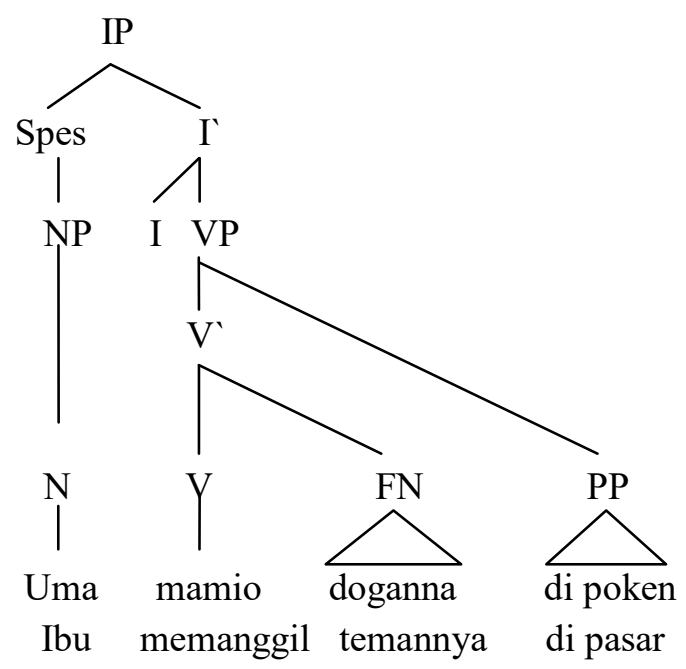

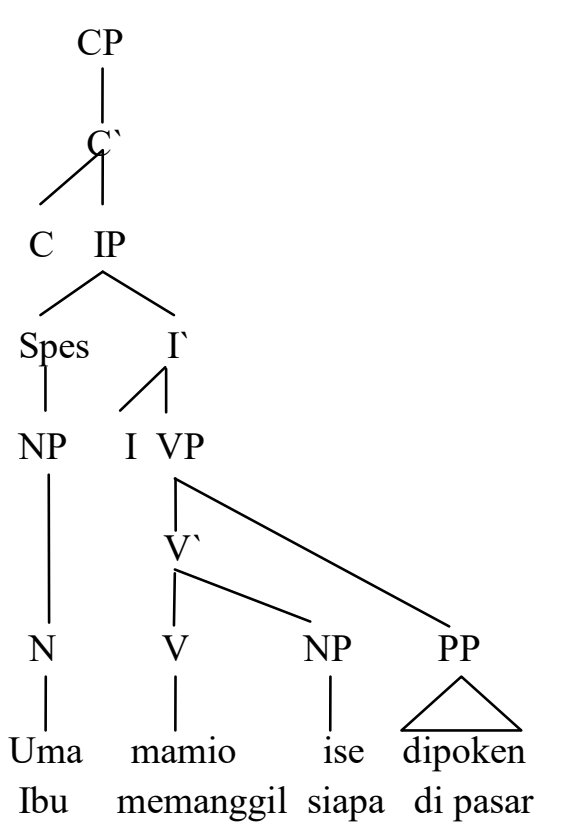

Gambar 4. Struktur Kalimat Tanya

Pada (1a), NP "doganna” bergabung dengan $V$ dan membentuk $V$ ' pertama dan merupakan komplemen dari VP. PP begabung dengan 
$\mathrm{V}^{\prime}$ pertama dan membentuk V' kedua dan kemudian langsung membentuk VP karena PP merupakan adverbia dari VP. VP adalah komplemen IP karena bergabung dengan I dan membentuk I'. NP "Uma" adalah bergabung dengan I' pertama dan membentuk IP dan merupakan spesifier.

Pada (2b), dapat dilihat bahwa struktur kalimatnya dengan (1b) adalah sama. Hanya saja pada kata "doganna" berubah menjadi "ise" yang artinya "siapa" karena kata "doganna" merupakan kata benda. Pada (1c), ada sedikit perbedaan. Posisi NP "ise" berpindah ke awal kalimat dan berfungsi sebagai spesifier. Berikut analisis struktur perpindahan kata tanya pada Gambar 5.

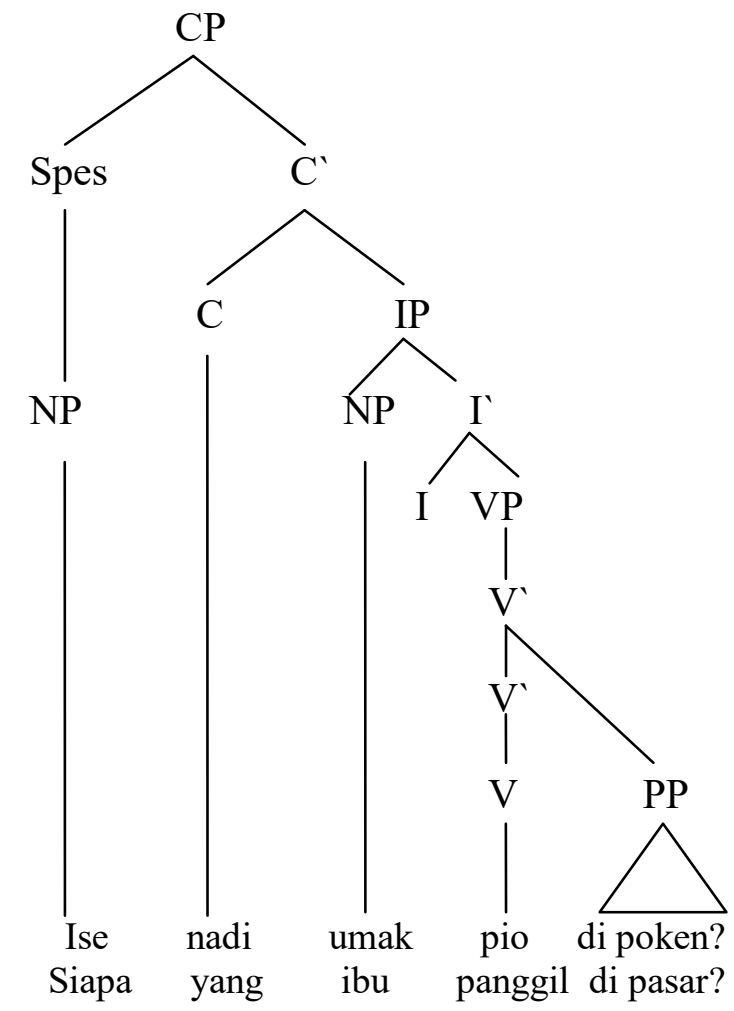

\section{Gambar 5. Struktur Perpindahan Kalimat Tanya}

Contoh kalimat tanya parsial lain yang bisa dianalisis dengan menggunakan teori X-bar ditunjukkan pada Gambar 6. Berdasarkan Gambar 6, NP adalah komplemen dari VP karena bergabung dengan $\mathrm{V}$ dan membentuk $\mathrm{V}$ ' pertama. VP adalah komplemen IP karena bergabung dengan I dan membentuk I'. Kata "Uma" berfungsi sebagai spesifier karena berkombinasi dengan I' dan membentuk IP. IP bergabung dengan $\mathrm{C}$ membentuk $\mathrm{C}^{\prime}$ lalu $\mathrm{C}^{\prime}$ akan membentuk CP. Kata tanya pada Gambar 6 berfungsi sebagai komplemen.

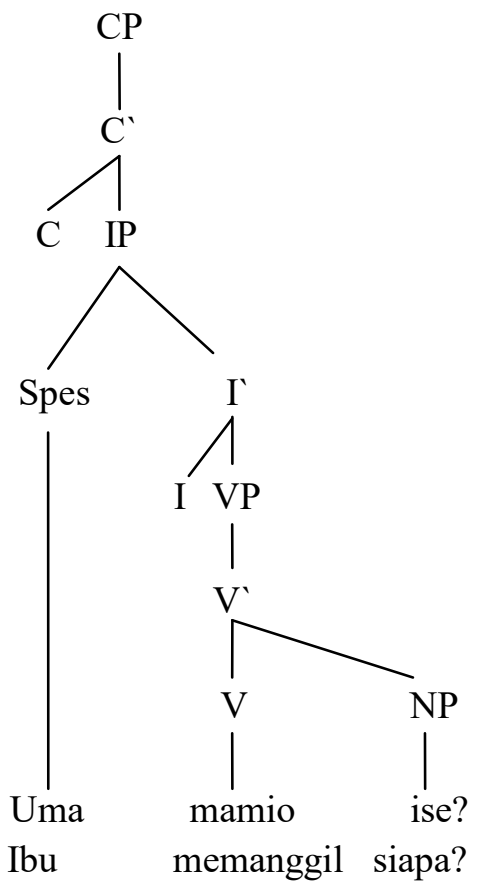

\section{Gambar 6. Struktur Lain Kalimat Tanya Parsial}

Analisis pada Gambar 5 dan Gambar 6 memiliki fungsi spesifier dan komplemen. Dikatakan memiliki fungsi spesifier apabila kata tanya diletakkan di depan kalimat karena kata tanya bergabung dengan C' yang akan membentuk proyeksi maksimal CP. Apabila kata tanya diletakkan di akhir kalimat maka memiliki fungsi komplemen karena kata tanya bergabung langsung dengan $\mathrm{V}$ dan membentuk $\mathrm{V}$ ' pertama. Dengan demikian, kata tanya dalam bahasa Mandailing apa (aha), siapa (ise), kapan (andigan), mengapa (asi), di mana (idia), bagaimana (songon) memiliki fungsi yang sama dan fungsi leksikal kata tanya tersebut adalah kata benda.

Selain kata tanya parsial, terdapat kata tanya total dalam bahasa Mandailing. Kalimat tanya total adalah kalimat tanya yang meminta informasi mengenai seluruh isi pertanyaannya (Irman, 2008:94-98). Kalimat Tanya total hanya menggunakan jawaban "ya" atau "tidak". Kalimat (12) sampai (16) adalalah contoh kalimat tanya total dalam bahasa Mandailing:

\section{Botul do Ayah mulak tu Jakarta natuari?}

(benarkah ayah pulang ke Jakarta besok?)

13. Ra doho jadi adborukku?

(maukah kamu menjadi istiku?) 
14. Adong do huting $i$ di kandang?

(adakah kucing itu dikandang?)

15. Tabo do panganon i?

(enakkah masakan itu?)

16. Giot do mangan sayur?

(sukakah kamu makan sayur?)

Kalimat yang dicontohkan menggunakan partikel -kah untuk menjadi sebuah kalimat tanya. Apabila dipakai dalam kalimat tidak kata tanya tetapi intonasinya adalah intonasi interogatif, maka -kah akan memperjelas kalimat itu sebagai kalimat interogratif (Alwi, 2003:307308).

Struktur kalimat deklaratif dan kalimat tanya total dapat dianalisis seperti pada Gambar 7 dan Gambar 8. Analisis pada Gambar 8 menjelaskan bahwa PP merupakan komplemen karena bergabung dengan $\mathrm{V}$ membentuk $\mathrm{V}$ ' pertama. NP "natuari" adalah adverb dari VP karena berkombinasi dengan V' pertama membentuk V' kedua, kemudian langsung membentuk VP. VP adalah komplemen dari IP karena berkombinasi dengan I dan membentuk I'. NP "ayah"adalah spesifier karena berkombinasi dengan I' dan membentuk IP. IP' begabung dengan $\mathrm{C}$ membentuk C' lalu C' menjadi CP.

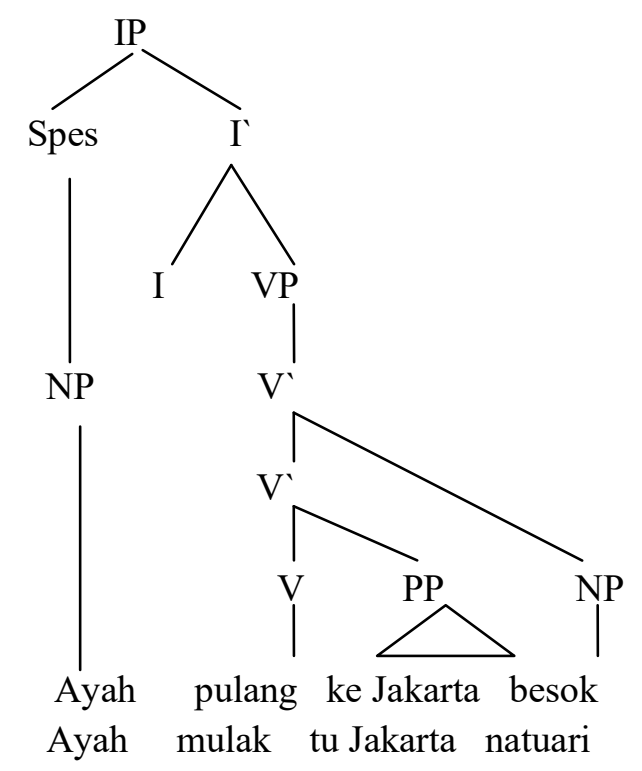

Gambar 7. Struktur Kalimat deklaratif
$\mathrm{CP}$

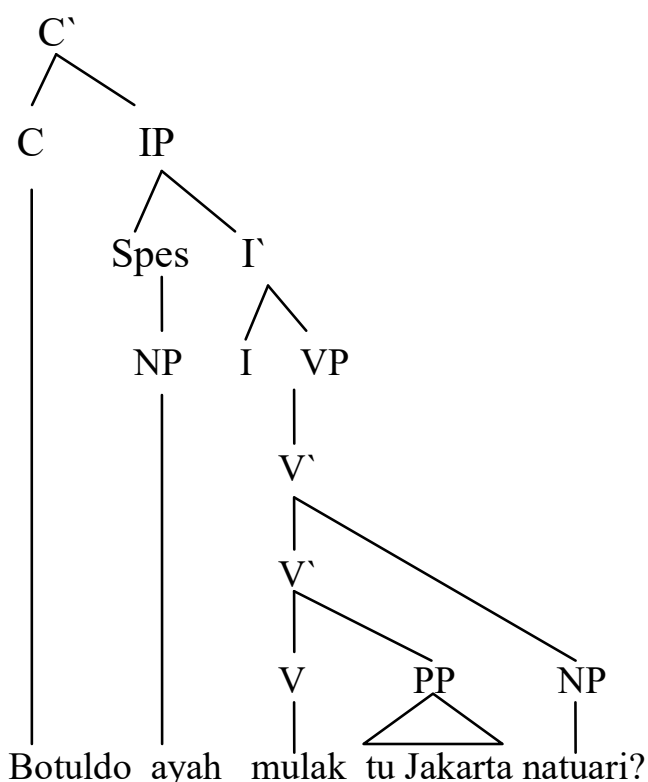

Benarkah ayah pulang ke Jakarta besok?

\section{Gambar 8. Struktur Kalimat Tanya Total}

Dalam bentuk kata tanya total, 'I' berubah menjadi kata "botuldo" yang berfungsi sebagai komplemen. Kata tanya "botuldo" tidak ditemukan di tengah atau akhir kalimat melainkan hanya di awal kalimat. Hal ini dapat dilihat pada kalimat (17) sampai (19).

17. a. *Ayah mulak botuldo tu Jakarta natuari?

b. *Ayah mulak botuldo tu Jakarta natuari botuldo?

18. a. *Mangan giot do sayur?

b. *Mangan sayur giot do?

19. a. *Panganon tabo do i?

b. *panganon i tabo do?

Jika dilihat kategori leksikalnya, yang dapat menempati posisi spesifier adalah NP. Hal ini dapat dilihat pada kalimat (20).

20. a. Uma mamio donganna di poken

$\begin{array}{llll}\mathrm{NP} & \mathrm{V} & \mathrm{NP} & \mathrm{PP} \\ \text { Spes } & & \end{array}$

b. Ise nadi uma pio di poken

NP Aux NP V PP

Spes 
Kategori leksikal yang dapat menempati posisi komplemen adalah auxiliary atau kata tambah, PP, atau NP. Hal ini ditunjukkan pada kalimat (21).

21. a. Uma mamio ise di poken

NP $\quad \mathrm{V} \quad \mathrm{NP} \quad \mathrm{PP}$

$C$

b. Ayah mulak tu Jakarta natuari $\begin{array}{llll}\mathrm{NP} & \mathrm{V} & \mathrm{PP} & \mathrm{NP}\end{array}$ C

c. Botuldo ayah mulak tu Jakarta natuari?

$$
\begin{array}{lllll}
\text { Aux NP V } & \text { PP NP }
\end{array}
$$$$
\text { C }
$$

Kategori yang dapat menduduki posisi adverbia adalah PP atau NP. Hal ini ditunjukkan pada kalimat (22).

22. a. Uma mamio donganna di poken $\mathrm{NP} \quad \mathrm{V} \quad \mathrm{NP} A d v \quad \mathrm{PP}$

b. Ayah mulak tu $\underline{\text { Jakarta natuari }}$ $\mathrm{NP} \quad \mathrm{V} \quad A d v \quad \mathrm{NP} \quad \mathrm{PP}$

Berdasarkan data yang telah dipaparkan dapat digambarkan aturan kalimat tanya bahasa Mandailing sebagai berikut.

Kalimat tanya parsial

$\left[\begin{array}{l}\mathrm{SPES} \\ \mathrm{NP}\end{array}\right]+\left\{\begin{array}{c}\mathrm{C} \\ \mathrm{NP} / \mathrm{PP}\end{array}\right]+\left[\begin{array}{c}\mathrm{ADV} \\ \mathrm{NP} / \mathrm{PP}\end{array}\right]$

Kalimat tanya total

$\left\{\begin{array}{c}\mathrm{C} \\ \mathrm{AUX}\end{array}\right]+\left\{\begin{array}{c}\mathrm{SPES} \\ \mathrm{NP}\end{array}\right]+\left\{\begin{array}{c}\mathrm{ADV} \\ \mathrm{NP} / \mathrm{PP}\end{array}\right]$

\section{Pembahasan}

Pembahasan penelitian didasarkan atas hasil yang telah dipaparkan. Hasil penelitian menunjukkan bahwa kalimat tanya dalam bahasa Mandailing terbagi atas kalimat tanya total dan kalimat tanya parsial. Struktur internal kalimat dalam bahasa Mandailing dikonstruksi oleh spesifier, komplemen, dan kata kerja. Spesifier harus ditempati oleh NP. Pelengkap dapat ditempati oleh auxiliary, PP, atau NP. Kata keterangan dapat ditempati oleh PP atau NP.
Struktur kalimat tanya parsial memiliki dua representasi sintaksis bergantung pada posisi dalam kalimat. Representasi pertama adalah sebagai spesifier, ketika ditempatkan di awal kalimat. Representasi kedua adalah sebagai pelengkap, ketika ditempatkan di akhir kalimat. Struktur kalimat tanya total seperti ' botuldo 'memiliki satu representasi sintaksis, yaitu sebagai komplemen.

Kalimat tanya bahasa Mandailing memiliki struktur yang sama dengan bahasa Indonesia. Penelitian sebelumnya oleh Masdiana (2008) menemukan bahwa struktur kalimat tanya bahasa Mandailing ditentukan oleh unsur pembentuk kalimat tanya itu sendiri dengan menggunakan fungsi leksikal dan fungsi gramatikalnya. Penelitian ini menggunakan analisis yang berbeda yaitu menggunakan diagram pohon (X-bar) mengenai struktur kalimat tanya dalam bahasa Mandailing.

Hasil penelitian ini sejalan dengan Fitriyani (2017) yang menemukan struktur kalimat tanya bahasa Minangkabau dibangun oleh komplemen, spesifier, dan keterangan dengan menggunakan teori X-bar. Temuan ini mendukung teori X-bar oleh Chomsky pada tahun 1970 dan dikembangkan lebih lanjut oleh Jackendoff (1977). Cilicover (1997:134) menyatakan bahwa teori X-bar adalah teori struktur frasa. Artinya, teori X-bar ini adalah teori yang dapat digunakan tentang ungkapan yang mungkin terjadi dalam bahasa biasa yang alami. Dengan demikian, teori X-bar juga dapat membedakan struktur satu bahasa dengan bahasa lainnya. Meskipun dijumpai perbedaan susunan kata pada bahasa-bahasa di dunia, perbedaan itu tetap dapat dijelaskan dalam teori X-bar (Tarigan, 1984:51 dalam Mulyadi, 2010:5).

Kebaruan penelitian ini dari penelitian terdahulu adalah pengkajian struktur kalimat tanya bahasa Mandailing dengan menggunakan teori $\mathrm{X}$-bar. Pengkajian struktur kalimat tanya oleh peneliti terdahulu hanya menggunakan fungsi leksikal dan gramatikal. Selanjutnya, beberapa pengkajian yang juga menggunakan teori X-bar, tetapi dengan bahasa yang lain.

Pengkajian struktur kalimat tanya bahasa Mandailing dengan menggunakan teori X-bar memberikan banyak manfaat. Memperhatikan struktur kalimat tersebut dapat membantu para pengguna bahasa melihat hubungan antar kata dalam sebuah kalimat dan membuat perbedaan 
struktur yang lebih tajam dan tepat antara satu bahasa dengan bahasa yang lain.

\section{PENUTUP}

Berdasarkan penelitian, dapat disimpulkan bahwa kalimat tanya dalam bahasa Mandailing terdiri atas kalimat tanya parsial dan kalimat tanya total. Kalimat tanya parsial dikatakan sebagai spesifier jika kata tanya diletakkan di awal kalimat. Sebaliknya, dapat dikatakan sebagai komplemen jika kata tanya berada di akhir kalimat. Kalimat tanya total dalam bahasa Mandailing, harus ditambah partikel -kah sehingga kata tanya tersebut memiliki fungsi komplemen. Pe-

\section{DAFTAR PUSTAKA}

Alwi, H. 2003. Tata Bahasa Baku Bahasa Indonesia. Jakarta: DepdikBud.

Chaer, A. 2011. Tata Bahasa Praktis Bahasa Indonesia. Jakarta: Rineka Cipta

Chaer, A. 2015. Sintaksis Bahasa Indonesia (Pendekatan Proses). Jakarta : Rineka Cipta.

Culicover, P. W. 1997. Principtes and Paramaters: An Introduction to Syntactic Theory. Oxford: Oxford University Press

Fitriyani, D Z. 2018. Interrgative Sentence in Minangkabau Language: X-bar Theory. Jurnal Retorika Ilmu Bahasa, 3 (1): 188-200.

Hafrianto, J. 2018. Kalimat Tanya dalam Bahasa Melayu Dialek Tamiang. Litera Jurnal Penelitian Bahasa, Sastra, dan Pengajarannya, 17(2): 186-201.

Harahap, R. 2018. Kata Tanya dalam Konstruksi Interogatif Bahasa Mandailing. School Education Journal, 8(1): 56-65. nelitian selanjutnya diperlukan analisis struktur jenis kalimat tanya bahasa Mandailing tidak hanya pada kalimat tanya total maupun parsial agar memberikan pemahaman yang lebih dalam tentang mengkaji struktur kalimat.

\section{UCAPAN TERIMA KASIH}

Terima kasih disampaikan kepada mitra bestari (reviewers) yang telah memberikan masukan, kritik, dan saran perbaikan dalam penulisan artikel ini. Ucapan terima kasih disampaikan pula kepada para informan yang telah membantu pengumpulan data penelitian.

Irman, M. 2008. Bahasa Indonesia 1. untuk SMK/ MAK Semua Program Keahlian Kelas X. Jakarta: Pusat perbukuan Departemen Pendidikan Nasional.

Kozok, U. 2009. Surat Batak . KPG.Jakarta.

Mulyadi. 2010. Frasa Preposisi Bahasa Indonesia : Analisis X-bar. Jurnal Kajian Sastra, 34 (1): 112.

Ramlan. 2005. Sintaksis. Yogyakarta:C.V. Karyono. Sudaryanto. 2015. Metode dan Aneka Teknik Analisis Bahasa Pengantar Penelitian Wacana Kebudayaan Secara Linguistis. Yogyakarta: Sanata Dharma University Press.

Sugiyono. 2006. Metode Penelitian Kuantitatif Kualitatif dan R\&D. Bandung: Alfabeta.

Sutopo, H. B. 2002. Metodologi Penelitian Kualitatif: Teori dan Aplikasinya dalam Penelitian. Surakarta: Sebelas Maret University Press. 